\title{
Reformulation of Dispute Resolution Mechanisms for Public Information Requests to Achieve Constructive Law Enforcement and Legal Certainty
}

\section{Peter Jeremiah Setiawan ${ }^{1}$, Xavier Nugraha ${ }^{2}$, Elma Putri Tanbun $^{3 \Omega}$}

\author{
${ }^{1}$ Faculty of Law, Universitas Surabaya \\ ${ }^{2,3}$ Faculty of Law, Universitas Airlangga \\ ${ }^{\Omega}$ email correspondence: Peterjsetiawan@staff.ubaya.ac.id
}

\begin{abstract}
The nature of law enforcement in resolving multi-dimensional information disputes has a logical consequence on the need for constructive law enforcement. This research aims to examine the forms of law enforcement that exist in resolving disputes over requests for public information and to formulate a constructive mechanism to realize a series of law enforcement procedures with legal certainty. This research is normative legal research using a statutory and conceptual approach. The results showed that law enforcement in the settlement of public information disputes consists of the objection, non-litigation adjudication, and litigation covering civil, state administration, and criminal law. In this case, The Criminal law instruments are placed as the final law enforcement if the relevant public agency does not carry out a decision that has permanent legal force. In addition, in the context of realizing comprehensive and constructive law enforcement, a Memorandum of Understanding was held between the Information Commission and the Police to synergize and effectively implement the criminal law as a final resort.
\end{abstract}

Keywords: Constructive Law Enforcement; Public Information Disclosure; Memorandum of Understanding; Dispute Resolution; Constructive Law;

DOI: http://dx.doi.org/10.33096/substantivejustice.v4i1.122

\section{INTRODUCTION}

Public information disclosure is one of the important elements in today's democracy. Public information disclosure is basically a step towards realizing clean and good governance by opening any information related to the state administration to the public. ${ }^{1}$ The characteristics of good governance vary widely, however, several main principles that underlie good governance

${ }^{1}$ Kristiyanto, E. N. (2016). Urgensi Keterbukaan Informasi dalam Penyelenggaraan Pelayanan Publik (Urgency of Disclosure of Informationin the Implementation of Public Service). Jurnal Penelitian Hukum De Jure, 16(2), pp. 231 244. http://dx.doi.org/10.30641/deiure.2016.V16.231-244 
consist of transparency, accountability, and community participation. ${ }^{2}$ Therefore, the application of public information disclosure is a form of implementing a transparent, participatory, and responsible democratic state in the entire process of public resources management.

Through information disclosure, the public can participate in supervising and actively participating in controlling every step and policy taken by the government so that the administration of the state can be held accountable to the people. ${ }^{3}$ This community control encourages transparent and accountable governance so as to limit the abuse of power in government. ${ }^{4}$ In other words, the existence of public information disclosure is a means to optimize oversight of state administration and anything that results in the public interest.

The Indonesian Constitution itself places the right to obtain information openly by every citizen as part of the human rights guaranteed by the constitution as stipulated in Article $28 \mathrm{~F}$ of the 1945 Constitution of the Republic of Indonesia (UUD NRI 1945). This provision stipulates that everyone has the right to seek, obtain, possess, store, process, and convey information using all available channels. The constitutional guarantee of the right to information is further regulated in Law No. 14 of 2008 On Freedom of Information (KIP Law). In addition, the birth of the Information Commission as an independent institution that functions to implement the KIP Law and its implementing regulations is a manifestation of the government's commitment to providing public information disclosure services to the public. ${ }^{5}$

The definition of public information according to Article 1 point 2 of the KIP Law is information that is generated, stored, managed, sent, and/or received by a public body related to state administration and administration and/or other public agencies and other information related to the public interest. Everyone including individuals, groups of people, legal entities, and public bodies has the right to obtain public information in accordance with the provisions of the KIP Law.

The legal consequence of such a right is an obligation for other parties to fulfill it. ${ }^{6}$ In correlation with the existence of the right to public information disclosure, it has juridical consequences, i.e the existence of an obligation for every public agency which, based on Article 1 point 3 of the KIP Law, which consists of the executive, legislative, judicial and other bodies whose main functions and duties are related to state administration, some or all of the funds come from the APBN/APBD or non-governmental organizations as long as the part or all of the funds come from the APBN/APBD, public donations, and/or abroad, political parties and BUMN/BUMD.

\footnotetext{
${ }^{2}$ Yarni, M. \& Amir, L. (2014). Penguatan Tata Kelola Pemerintahan yang Baik dalam Pembentukan Peraturan Perundang-Undangan sebagai Pilar Penegakan Hak Asasi Manusia di Indonesia. Jurnal Ilmu Hukum Jambi, 6(1), pp. 120 $-138$.

${ }^{3}$ Retnowati, E. (2012). Keterbukaan Informasi Publik dan Good Governance (Antara Das Sein dan Das Sollen). Perspektif, 17(1), pp. 54 - 61. http://dx.doi.org/10.30742/perspektif.v17i1.94

${ }^{4}$ Sunarko, T. A., Jaya, I. N. S. P., \& Purwoto. (2012). Pertanggungjawaban Pidana Pejabat Publik terhadap Tindak Pidana Kebohongan Publik dalam Undang-Undang Nomor 14 Tahun 2008 Tentang Keterbukaan. Diponegoro Law Journal, 1(4), pp. 2 - 11.

${ }_{5}$ Aryani P., Dyah, et.al. (2015). Putusan Komisi Informasi dalam Bingkai Hukum Progresif. Jakarta: Komisi Informasi Pusat Republik Indonesia, p. 1.

${ }^{6}$ Nugraha, X., \& Katherina, A. M. F. (2019). Tanggungjawab Promotor Perseroan Terbatas Terhadap Kontrak Prainkorporasi Di Indonesia. Media luris, 2(1), pp. 99 - 128.
} 
The implementation of responsibility for the fulfillment of the right to public information by public agencies is of course not just an obligation but contains the essence that this public information must be conveyed properly and correctly, both in terms of procedures and in terms of substance. ${ }^{7}$ This is then confirmed in Article 7 paragraph (2) of the KIP Law which states that public agencies are required to provide public information that is accurate, true, and not misleading.

Article 2 paragraph (1) of the KIP Law explains that any public information is open and can be accessed by any user of public information. Based on the UU KIP, public information is classified into several categories, namely public information that must be announced periodically, public information that must be announced immediately, information that must be available at any time, and information that is exempted. In addition, everyone has the right to submit requests for public information to public bodies including public information that is not included in the information classification as described above. In this case, applications are submitted to public bodies through the Information and Documentation Management Officer (PPID) as the official responsible for storing, documenting, providing and/or providing information services in each public body.

In the implementation of this public information service, there is a possibility of a dispute between the applicant and the public information provider (public agency). Article 1 point 5 of the KIP Law states that public information disputes are disputes that occur between public agencies and users of public information relating to the right to obtain and use information based on statutory regulations. A public information dispute arises if there is a reason to file an objection to the PPID supervisor against a request for information to a public body. For example, refusal of requests for information because it includes exempt information. The exception to information is based on testing by PPID about the consequences that arise if the information is provided to the public before declaring public information as exempt information. ${ }^{8}$ This matter, in turn, can lead to disputes due to differences in views and interests between public agencies and requesters of information. In addition, disputes can be in the form of refusal of public bodies to provide the information requested by the applicant, not being responded to or fulfilled by requests for information, the information provided incomplete, inadequate or incorrect, imposition of unreasonable fees, and/or submission of information that exceeds the time that has been passed. stipulated in the KIP Law. ${ }^{9}$ Disputes can also occur because public bodies do not provide or publish public information regularly, public information that must be announced immediately and/or public information that must be available at any time. ${ }^{10}$

\footnotetext{
${ }^{7}$ Mushi, A. (2018). Pemenuhan Hak atas Informasi Publik sebagai Tanggung Jawab Negara dalam Mewujudkan Good Governance. Lentera Hukum, 5(1), pp. 63 - 76. https://doi.org/10.19184/eilh.v5i1.7284

${ }^{8}$ Retnowati, E. Op. Cit., p. 57.

${ }^{9}$ Prasetyo, T. (2016). Penyelesaian Sengketa Keterbukaan Informasi Publik di Pengadilan Tata Usaha Negara Semarang. Jurnal Spektrum Hukum, 13(2), p. 238 - 261. http://dx.doi.org/10.35973/sh.v13i2.1091

${ }_{10}$ Haugen, T., \& Singh, A. (2015). Dispute Resolution Strategy Selection. Journal of Legal Affairs and Dispute Resolution in Engineering and Construction Vol, 7(3). https://doi.org/10.1061/(ASCE)LA.1943-4170.0000160
} 
Regarding the disputes, the KIP Law regulates certain law enforcement efforts consisting of objections to the relevant public bodies, non-litigation adjudication through the Information Commission, lawsuits to courts including the District Court (Pengadilan Negeri) or State Administrative Court (Pengadilan Tata Usaha Negara) as well as filing an appeal to the Supreme Court. ${ }^{11}$ In addition, the KIP Law also regulates the enforcement of criminal law, whereby information applicants can report the relevant public bodies criminally as stipulated in Article 52 of the KIP Law.

The existence of various legal remedies provided in the KIP Law, shows that law enforcement of public information disputes is multidimensional, both non-litigation, as well as civil litigation or state administration (depending on the type of public body), and criminal. The question that arises is whether the public agency concerned can be reported directly in a criminal manner or must go through non-litigation adjudication through the Information Commission, then a lawsuit and cassation first, so that criminal law enforcement is placed as an ultimum remedium or should law enforcement procedures be carried out simultaneously. There is still no regulation related to a clear sequence of procedures which has the potential to create uncertainty in law enforcement. For example, at the cassation level, the Supreme Court stated that the information requested was not public, but it turned out that the case file of the reported party had already been determined as P-21. This shows the potential for dualism or overlapping between law enforcement.

The absence of a clear sequence related to the settlement of disputes regarding prior information requests or enforcement of criminal law first is what actually has the potential to create legal uncertainty related to this law enforcement sequence. The principle of legal certainty is needed in the creation of laws and regulations because legal certainty is the main principle of various kinds of principles of the rule of law. ${ }^{12}$ This is coherent with M. Kordela's opinion, which stated:13 "The legal certainty as the superior principle of the system of formal principles of the rule of law justifies the legal validity of a defined group of values".

The absence of regulations that regulate the multidimensional law enforcement order has the potential to lead to unconstructive law enforcement. This unconstructive law enforcement then creates legal uncertainty and problems, especially when the decisions issued later contradict one another. Therefore, a constructive law enforcement mechanism is needed to provide legal certainty for the delivery of public information to the public.

Based on the description above, the problems that will be examined in this paper are, First, forms of law enforcement in resolving disputes over requests for public information based

${ }^{11}$ Prasetyo, T. ibid.

12 Indratanto, S. P., Nurainun, N., \& Kleden, K. L. (2020). Asas Kepastian Hukum Dalam Implementasi Putusan Mahkamah Konstitusi Berbentuk Peraturan Lembaga Negara Dan Peraturan Pemerintah Pengganti Undang-Undang. DIH: Jurnal Ilmu Hukum, 16(1), pp. 88 - 100. https://doi.org/10.30996/dih.v16i1.2729

${ }^{13}$ Kordela, M. (2008). The Principle of Legal Certainty as a Fundamental Element of the Formal Concept of the Rule of Law. Revue Du Notariat, 2(1), pp. 590 - 598. https://doi.org/10.7202/1045553ar 
on statutory regulations. Second, the formulation of a law enforcement mechanism in resolving disputes over requests for constructive public information.

There are several articles in legal journals that are similar to this one. Some of these articles are:

1. Article by Arif Widi Fatoni entitled: "Settlement of Disputes on Public Information Disclosure through Adjudication in Law Number 14 of 2008 concerning Public Information Openness" published in the lus Constituendum Journal, Volume 4, Number 1 , in 2019. The focus of the discussion is related to the difficulty of presenting the petitioner and the respondent in resolving information disputes so that the dispute resolution mechanism for public information disclosure through adjudication in law number 14 of 2008 on information disclosure takes a long time. This focus is certainly different from this article, which focuses on reconstructing the mechanism for resolving disputes over requests for public information to create constructive law enforcement and reflect legal certainty.

2. Article by Tony Prasetyo entitled: "Settlement of Disputes on Public Information Disclosure at the Semarang State Administrative Court" published in the Journal of Legal Spectrum, Volume 13, Number 2, in 2016. In this article the focus of discussion is related to dispute resolution mechanisms. disclosure of public information in PTUN which incidentally means a dispute over information disclosure with state public agencies. This focus is certainly different from this article, in which the focus is not only on resolving disputes on public information disclosure in the PTUN but also in district courts. In addition, the focus of this article is to reconstruct the dispute resolution mechanism for requests for public information to create constructive law enforcement and reflect legal certainty.

\section{METHOD}

This research uses normative legal research, which is research that puts law as a norm system building consisting of principles, norms, rules of statutory regulations, court decisions, agreements and doctrines. ${ }^{14}$ Normative research is carried out by analyzing statutory regulations or other legal materials related to public information disclosure.

The approach used is a statutory conceptual approach. The statutory approach is carried out by reviewing all laws and regulations and regulations relating to the legal issues under study. ${ }^{15}$ In this study, researchers investigated all laws and regulations related to public information disclosure, especially the resolution of public information disputes.

${ }^{14}$ Sonata, D. L. (2014) Metode Penelitian Hukum Normatif dan Empiris: Karakteristik Khas dari Metode Meneliti Hukum. Fiat Justitia Jurnal IImu Hukum, 8(1), pp. 15 - 35.

${ }^{15}$ Marzuki, M. (2017). Penelitian Hukum (Edisi Revisi). Jakarta: Kencana Prenadamedia Group, p. 133. 
The conceptual approach is carried out by examining the development of views or doctrines in the science of law. ${ }^{16}$ Through a conceptual approach, ideas that give birth to concepts, definitions, and legal principles that are relevant to the legal issues being studied can be identified. This approach is carried out with an understanding of the concept of disclosure of public information and the concept of procedural law for public information dispute resolution.

\section{ANALYSIS AND DISCUSSION}

\section{A. Forms of Law Enforcement in Disputes Resolution on Requests for Public Information based on the statutory regulations.}

Before discussing forms of law enforcement, it is better if we understand how the procedures for requesting public information have been stipulated in statutory regulations. Every person who submits a petition must observe the rule of law in Decision No. 509 / K / TUN / 2013 dated 23 January 2013 which has been designated as Jurisprudence. Jurisprudence is the decisions of a judge or court that are permanent and justified by the Supreme Court as a court of cassation or the decisions of the Supreme Court itself which are permanent. ${ }^{17}$ Decisions that have value as jurisprudence are decisions justified by the Supreme Court as a jurisprudence.

As for the rule of law in the a quo jurisprudence states that: "However, in examining disputes on the Disclosure of Public Information, it must be considered whether there are interests that have implications for the legal standing of the Plaintiff. This is in line with the point d'interest point principle. Thus, the applicant submitting a request for public information should be a party that has an interest in the information. This is important to prevent the possibility of this information from being misused by irresponsible parties. Subsequently, requests for public information are made based on the principles of fast, timely, and low $\operatorname{cost}^{18}$ with the following flow: ${ }^{19}$

${ }^{16}$ Barus, Z. (2013). Analisis Filosofis tentang Peta Konseptuan Penelitian Hukum Normatif dan Penelitian Hukum Sosiologis. Jurnal Dinamika Hukum, 13(2), pp. 307 - 318. http://dx.doi.org/10.20884/1.jdh.2013.13.2.212

${ }_{17}$ Simanjutak, E. (2019). Peran Yurispridensi dalam Sistem Hukum Indonesia. Jurnal Konstitusi, 16(1), pp. 83 104. https://doi.org/10.31078/ik1615

${ }^{18}$ In the explanation of Article 2 paragraph (3) of the KIP Law, what is meant by "timely" is that the fulfillment of requests for information is carried out according to the time stipulated in the statutory regulations. The simple way is that the requested information can be accessed easily in terms of procedures and also easy to understand. Meanwhile, "low cost" is a fee that is charged proportionally based on cost standards in general.

${ }^{19}$ KIP Law and Information Commissions Regulation No. 1 of 2010 On The Public Information Service Standards. 
Diagram 1. Public Information Request Flow

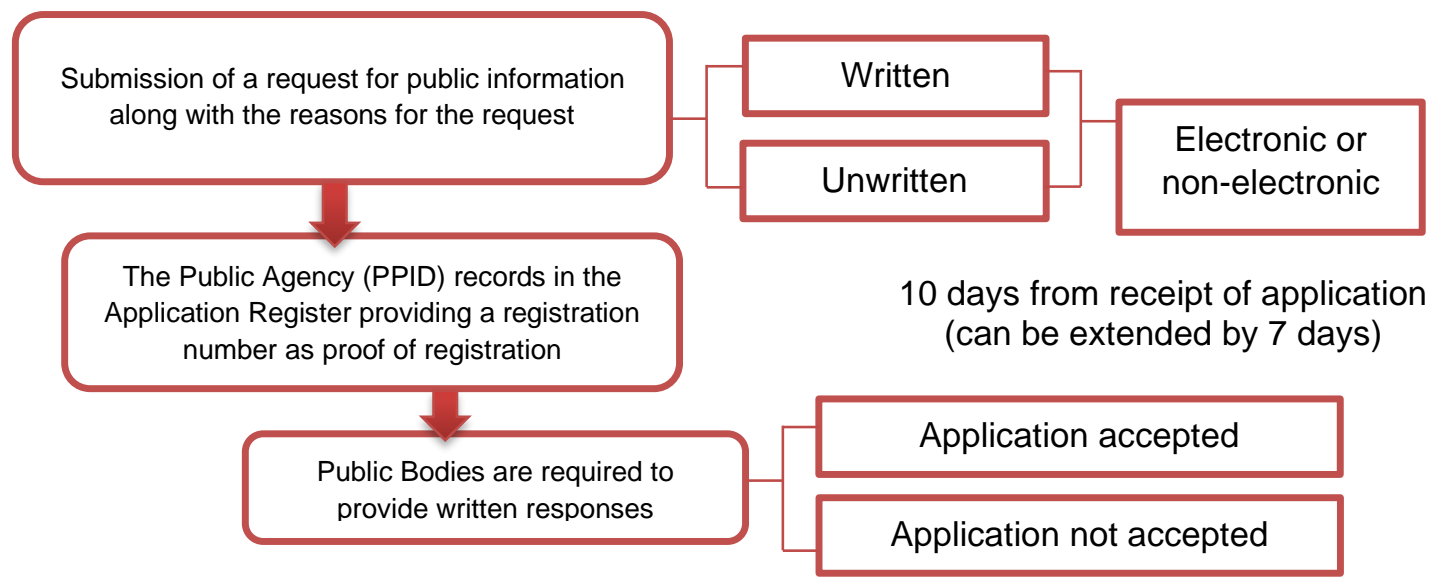

Source: Information Commission Regulation No. 1 of 2010 concerning Public Information Service Standards

With the written response from the public body concerned, it is possible that the applicant for information was not satisfied. For example, if the request is rejected, it could be because the information requested includes exempt information, the information provided is not as requested, incomplete, the imposition of unreasonable fees, and/or the delivery of information that exceeds the time specified in the laws and regulations. There is even a possibility that the petitioner will not be responded to or not fulfilled by the public body. This dissatisfaction can then lead to a dispute between the applicant and the public agency concerned so that law enforcement efforts are needed to resolve the dispute. Law enforcement is an activity to implement and apply the law and take legal action against any violation of the law committed by legal subjects either through judicial procedures or through arbitration procedures and other dispute resolution mechanisms (alternative disputes or conflict resolution) ${ }^{20}$ Based on this opinion, law enforcement is applying the law to resolve violations or disputes.

In the KIP Law, various mechanisms for resolving information disputes have already been regulated. The first option is in dispute resolution through the information commission, namely Dispute Resolution through the Information Commission. The Information Commission has the authority to resolve disputes over requests for information through adjudication between information requesters and public bodies ${ }^{21}$ According to Article 1 number 9 Information Commission Regulation No. 1 of 2013, Adjudication is the process of resolving public information disputes between the parties in a trial decided by the Information Commission. The authority of the Information Commission to resolve disputes through non-litigation adjudication is related to

${ }^{20}$ Asshidiqie, J. (2006). Hukum Tata Negara dan Pilar-Pilar Demokrasi, Serpihan Pemikiran Hukum, Media dan HAM. Jakarta: Syaamil Cipta Media, p. 386.

${ }^{21}$ Lolita, A \& Abudan, M. (2018). Kewenangan Komisi Informasi dalam Mengadili Sengketa Informasi Publik (Studi Kasus: Forum Diskusi Suporter Indonesia Melawan Persatuan Sepak Bola Seluruh Indonesia, Jurnal Hukum Adigama, 1(1), pp. 1 - 25. http://dx.doi.ora/10.24912/adiqama.v1i1.2134 
the position of the Information Commission as a semi-judicial (quasi-judicial) institution. ${ }^{22}$ The term quasi-judicial refers to an institution that is not a court but has the authority to hear and decide a case. ${ }^{23}$ The institution's decision has the same legal force as the court's decision, it is even final and binding as the court's decision is inkracht. ${ }^{24}$

Non-litigation law enforcement through the Information Commission is specifically regulated in Information Commission Regulation No. 1 of 2013 on The Procedures for Public Information Dispute Resolution (ICR No. 1 of 2013). Before entering the adjudication stage, there is a procedure that must be carried out by the applicant, i.e the information applicant has submitted an objection to the PPID's written response to the information request he submitted. To this objection, PPID provided a written answer. If the applicant for information is satisfied with the PPID's answer, the dispute ends. On the other hand, if the applicant for information is not satisfied or the PPID does not provide an answer within 30 days, the applicant can submit a request for law enforcement through the Information Commission. Applications are submitted no later than 14 working days from the applicant's receipt of a written answer to the objection, or the expiration of the period for the PPID supervisor to provide a written answer.

Article 4 ICR No. 1 of 2013 confirms that requests for dispute resolution through the Information Commission must be submitted and followed seriously and in good faith. In the Decree of the Chairman of the Central Information Commission No.01/KEP/KIP/V/2018 concerning Procedures for Termination of Public Information Dispute Resolution Processes That Are Not Done Seriously and in Good Faith, the criteria for such applications are requests submitted in large numbers at once, submitted repeatedly for reasons that are not clear or irrelevant to the purpose of the application, submitted to interfere with the dispute resolution process and/or submitted accompanied by harassment to the dispute resolution officer with treatment outside the dispute resolution procedure, for example using harsh words both verbally and non-verbally and/or doing violence.

The Information Commission has the right not to respond to requests and determine a decision to terminate the dispute resolution process if the results of the examination prove that the applicant is not sincere and has good intentions. This provision aims to prevent irresponsible requests, just for fun or without clear intent and purpose as mandated by the KIP Law. In the end, this will actually hinder the tasks of state administration that are carried out by public agencies. The non-litigation adjudication law enforcement by the Information Commission is carried out by the Board of Commissioners which consists of at least 3 commission members or more and must

22 Furqon, E. (2020). Kedudukan Lembaga Negara Independen Berfungsi Quasi Peradilan dalam Sistem Ketatanegaraan Indonesia. Jurnal Nurani Hukum, 3(1), pp. 77 - 85. http://dx.doi.ora/10.51825/nhk.v3i1.8523

${ }^{23}$ Risnan, M. (2014). Eksistensi Lembaga Quasi Judicial dalam Sistem Kekuasaan Kehakiman: Kajian Terhadap Komisi Persaingan Usaha', Jurnal Hukum dan Peradilan, 3(1), pp. 49 - 58.

24 Ibid. 
be an odd number. Information Commission hearings are open to the public, except for hearings in the case of an exempted request for information.

In general, the material that will be examined by the Board of Commissioners in the adjudication process includes procedural and substantive aspects. The procedural aspect focuses on technical administration starting from the stages of submitting requests for public information, filing objections, submitting requests for resolving public information disputes, and completing the legal standing of the applicants. Meanwhile, the substantive aspect focuses on the material of public information that is requested or which becomes a public information dispute. The dispute resolution process is carried out on the principles of fast, precise, low cost, and simple with the following flow:

Diagram 2. Flow of the Law Enforcement Process through the Information Commission

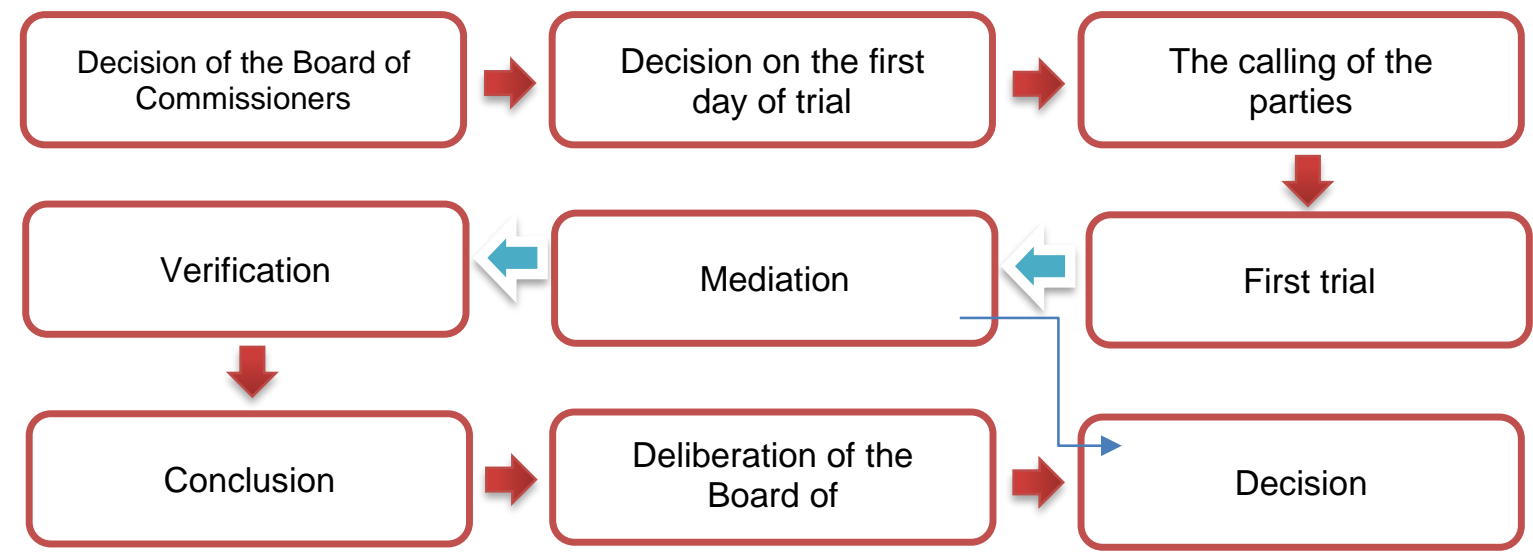

Source: Information Commission Regulation No. 1 of 2013 concerning Public Information Dispute Resolution Procedures

Regarding the decision from the Commission, one or both parties who do not accept the decision of the Information Commission can file a lawsuit at the competent court within 14 days from the receipt of the copy of the informed decision by the parties. On the other hand, if the parties do not file a lawsuit, the decision of the Information Commission is legally binding (inkracht van gewijsde) 14 days after a copy of the informed decision is received by the parties. A decision from the Information Commission that has legal force can still be requested for execution at the head of the court who is authorized by the requestor for information.

Subsequent law enforcement is the enforcement of litigation law through courts as regulated in Supreme Court Regulation No. 2 of 2011 concerning Procedures for Resolving Public Information Disputes in Courts (Perma No.2 of 2011). This law enforcement can only be done if one or both parties declare in writing that they do not accept the adjudication decision of the Information Commission. This is because the object of examination in court is the adjudication 
decision of the Information Commission. The court is not authorized to accept, examine, and decide on a case submitted if the objection and litigation adjudication has not been made. ${ }^{25}$

The court, in this case, includes the PTUN if the defendant is a state public body and the PN if the accused is a public body other than a state public body. ${ }^{26}$ State Public Bodies include the executive, legislative, judiciary and other bodies whose main functions and tasks are related to the administration of the state which partially or all of the funds come from the APBN/APBD. Meanwhile, public bodies other than state public agencies are BUMN, BUMD, non-governmental organizations and political parties whose funds partly or all originate from the APBN/APBD, public donations, and/or abroad.

A lawsuit is filed by an information applicant or a public body to a court whose jurisdiction includes the domicile of the public body. No later than 14 days after the lawsuit is registered at the Registrar's Office of the Court, the clerk of the court asks the Information Commission which decided the case to send an official copy of the disputed decision and all the files of the case no later than 14 days after the request is filed. The Respondent can submit a response to the lawsuit to the court clerk within 30 days of the objection being registered. The use of the phrase "can" indicates that a response to the claim is not an obligation. Furthermore, no later than 3 days after the deadline for submission of answers, the Chairman of the Court shall appoint a panel of judges who hear the case in which the panel of judges as much as possible consists of judges who comprehend the field of information disclosure.

The panel of judges after studying and examining the case files then conducts a deliberation meeting of the judges to determine the verdict and goes directly to the process of reading the verdict. ${ }^{27}$ Referring to Article 7 paragraph (1) Perma No. 2 of 2011, the examination is carried out simply. A simple examination has the purpose of that examination is only carried out on the decision of the Information Commission, case files, lawsuits and responses to written claims from the parties. Examinations are carried out without mediation and evidence examinations are only carried out on matters that have been denied by one or both parties. If new evidence is found in the examination, the panel will examine the evidence by ordering the substitute clerk to summon the parties. The Assembly may also call the Information Commission when needed.

The court is obliged to decide within 60 days from the time the panel of judges is appointed. The verdict is pronounced in a hearing which is open to the public, except concerning exempt information. The decision can be in the form of canceling or affirming the decision of the Information Commission and/or overturning the decision of the Information Commission and

${ }^{25}$ Prasetyo, T. Op. Cit., p. 245.

26 Febrianingsih, N. (2012). Keterbukaan Informasi Publik dalam Pemerintahan Terbuka Menuju Tata Pemerintahan yang Baik. Jurnal Rechtsvinding, 1(1), pp. 135 - 156. http://dx.doi.org/10.33331/rechtsvinding.v1i1.110

${ }^{27}$ Naelufar, R. (2013). Perluasan Kompetensi PTUN dalam Mengadili Sengketa Informasi Publik. UNNES Law Journal, 2(1), pp. 64 - 72. https://doi.org/10.15294/uli.v2i1.2905 
accompanied by an order to the public body to provide or reject part or all of the information requested by the applicant. Regarding this decision, one of the parties can file a cassation action to the Supreme Court no later than 14 days after the decision is read out if the parties are present or if the parties are not present, then 14 days after the PN bailiff informs the parties the contents or warnings of the verdict sent by post for disputes at PTUN. If the parties do not file an appeal, the decision has permanent legal force (inkracht van gewijsde) and has executorial power.

Apart from going through a lawsuit, the KIP Law also regulates the enforcement of criminal law as regulated in Article 52 of the KIP Law as follows:

"Public Bodies that deliberately do not provide, do not deliver, and/or do not publish Public Information in the form of Public Information periodically, Public Information which must be announced immediately, Public Information which must be available at any time, and/or Public Information which must be published immediately. granted based on a request following this Law, and results in losses for other people being subject to a maximum imprisonment of 1 (one) year and/or a maximum fine of Rp. 5,000,000.00 (five million rupiah)".

The criminal process in public information disputes constitutes a complaint offense as regulated in Article 57 of the KIP Law. Lamintang explained that the complaint offense means that a criminal act can only be prosecuted if there is a complaint from the aggrieved party. ${ }^{28}$ Therefore, in the case of this request for information, a criminal process can only be carried out by law enforcement officials if there is a complaint to law enforcers, in this case, the police regarding an alleged criminal act of public information.

The formulation of criminal sanctions in Article 52 of the KIP Law is alternativecumulative, as seen by the use of the phrase "and/or", namely imprisonment for a maximum of 1 year and/or a maximum fine of Rp.5,000,000.00 (five million rupiahs). Therefore, in the case of this request for information, a criminal process can only be carried out by law enforcement officials if there is a complaint to law enforcers, in this case, the police regarding an alleged criminal act of public information. ${ }^{29}$ Criminal sanctions are imposed on public bodies and public officials (persoon) who are proven to have committed acts outside their main duties and functions by exceeding their powers stipulated in the laws and regulations and provisions of the relevant public bodies. In the elucidation of Article 52 of the KIP Law, penalties are imposed on those who give orders to commit criminal acts or who act as leaders in committing criminal acts. Meanwhile, for fines, Article 19 of Government Regulation no. 61 of 2010 concerning the Implementation of the KIP Law states that the payment of criminal fines for public agencies is borne by the finances of the public bodies concerned. Criminal fines are personal responsibility and do not become a financial burden on a public body if it is proven that the person concerned has not carried out his duties and obligations as stipulated in the laws and regulations and provisions of the public

\footnotetext{
${ }^{28}$ Lamintang, P.A.F. (1997). Dasar-Dasar Hukum Pidana Indonesia. Bandung: Citra Aditya Bakti, p. $217-218$.

${ }^{29}$ Saraya, Sitta. (2019). Tindak Pidana Keterbukaan Informasi Publik di Indonesia Sebuah Kajian Perbandingan Sistem Pemidanaan di Negara Asing Thailand dan Jepang. Jurnal Ius Constituendum, 4(2), pp. $128-146$. http://dx.doi.org/10.26623/iic.v4i2.1653
} 
agency. In addition, criminal fines to public bodies do not reduce the state's right to impose sanctions. Administrative towards the public officials concerned.

If the defendant or public prosecutor does not file a legal remedy, the verdict is legally binding and can be executed by the prosecutor based on the type of decision handed down. Meanwhile, if the defendant or the public prosecutor is not satisfied with the result of the decision at the first instance court, then legal remedies are available. Legal remedies in the Criminal Procedure Code consist of ordinary remedies (gewone rechtsmiddelen) and extraordinary remedies (buiten gewone rechtsmiddelen). ${ }^{30}$ Usual remedies include resistance, appeal, and cassation. After all legal remedies have been taken, the decision has permanent legal force and the prosecutor can execute the decision based on the type of decision handed down. While extraordinary legal remedies include cassation for legal purposes and review of court decisions that have permanent legal force (inkracht van gewijsde). ${ }^{31}$

\section{B. Formulation of a Constructive Public Information Request Dispute Resolution Mechanism}

The nature of law enforcement in resolving multi-dimensional information disputes has a logical consequence on the need for constructive law enforcement. Basically, constructive law enforcement is all efforts to improve and build a structure ${ }^{32}$ so that the law enforcement process becomes a series of procedures that reflect the objectives of law, namely justice, legal certainty and benefit. ${ }^{33}$

The KIP Law and several related regulations have indeed regulated a series of law enforcement procedures in the event of a sequential information dispute, starting from objection, non-litigation adjudication, lawsuits to cassation, but there are still 2 (two) problems, so there is still no clear procedural order so that it has the potential to create uncertainty in resolving disputes over constructive public information requests. The first problem is related to the content of the rules. The KIP Law does not confirm that criminal charges according to Article 52 of KIP have the ultimum remidium in nature for resolving public information disputes. In fact, the criminal prosecution and the public information dispute settlement process have the same law enforcement substance and are interconnected. The criminal element according to Article 52 of KIP with the material of public settlement disputes has the same thing, which is basically regarding the acquisition and use of public information. Thus, this regulation does not clearly describe the position of criminal law enforcement. If traced further, there has been a Circular Letter of the

${ }^{30}$ Simamora, J. (2014). Kepastian Hukum Pengajuan Kasasi oleh Jaksa Penuntut Umum terhadap Vonis Bebas: Kajian Putusan Mahkamah Konstitusi Nomor 114/PUU-X/2012. Jurnal Yudisial, 7(1), pp. 1 - 17. http://dx.doi.org/10.29123/iv.v7i1.90 $234-243$.

${ }^{31}$ Korua, R. V. (2020). Kajian Hukum Putusan Bebas (Vrijspraak) dalam Perkara Pidana. Lex Crimen, 9(4), pp.

${ }^{32}$ Cahyo, A. N. (2013). Panduan Aplikasi Teori-Teori Belajar Mengajar Teraktual dan Terpopuler. Jogjakarta: Diva Pers, p. 33.

${ }^{33}$ Erwin, M. (2012). Filsafat Hukum. Jakarta: Raja Grafindo, p. 123 
Information Commission No. 1 of 2012 on The Handling of Criminal Acts in the UU KIP. The a quo circular basically states that criminal charges in Article 52 of the KIP Law can be made when the Information Commission's decision is legally enforceable so that the criminal process without a decision on public information dispute resolution by the Information Commission cannot proceed.

Based on the Information Commission Circular Letter No. 1 of 2012 On The Handling of Criminal Acts in the KIP Law, it can be understood that criminal acts only exist when the public agency concerned does not carry out the Information Commission's decision which has permanent legal force. The use of the phrase that the Information Commission's decision has legal force by itself can cause confusion because it creates the perception that the decision only reaches the non-litigation adjudication stage. In fact, non-litigation adjudication decisions can still be filed for a lawsuit, which verdicts can be in the form of canceling or strengthening the decision of the Information Commission. Thus, the decision of the Information Commission is legally binding if no further legal remedies are filed, either lawsuit or cassation as described in the previous discussion.

The second problem is related to the position and strength to bind the existing rules. The only legal products that regulate those related to criminal law enforcement are circular letters. In Article 8 of Law Number 12 of 2011 On The Formation of Legislative Regulations (Law 12/2011) which was later amended by Law Number 15 of 2019, it is stipulated that: "(1) Types of Legislation other than those referred to Article 7 paragraph (1) includes regulations stipulated by the People's Consultative Assembly, the People's Representative Council, the Regional Representative Council, the Supreme Court, the Constitutional Court, the Supreme Audit Agency, the Judicial Commission, Bank Indonesia, Ministers, agencies, institutions or commissions of the same level. which is formed by law or by the government at the behest of the law, the Provincial Regional People's Representative Council, the Governor, the Regency/City Regional People's Representative Council, the Regent / Mayor, the Village Head or equivalent. (2) Legislation as referred to in paragraph (1) is recognized for its existence and has binding legal force as long as it is ordered by the higher laws and regulations or is established based on authority (thickening by the author). " From the grammatical interpretation of Article 8 Law number 15 of 2019 on The revision to Law Number 12 of 2011 on the Establishment of Legislations, it can be seen that those qualified into statutory regulations which are generally binding based on Article 1 number 2 of Law 15/2019 are only products in the form of regulations, and not circular.

The status of a circular is a legal product in the form of a beleidsregel (policy regulation). ${ }^{34}$ This regulation is referred to as a policy rule because it contains a policy line that is determined

${ }^{34}$ Belinfante A. D. (1983). Pokok-Pokok Hukum Tata Usaha Negara. Jakarta: Bina Cipta, p. 84. 
administratively by the relevant agencies. ${ }^{35}$ In terms of binding strength, this policy regulation is arguably not as strong as statutory regulations (regelend). Thus, it can be understood that the validity of this circular letter is only internal to the issuing institution. Based on its enactment, some call this circular letter a pseudo wetgeving law.

From its essence as a circular, a circular should not contain norms of behavior (gedrags normen), norms of authority (bevoegdheids normen), and stipulations (bepalende normen) ${ }^{36}$, but only contains administrative instructions of an internal nature, which are intended to provide further instructions regarding a general statutory norm. However, Information Commission Circular Letter No. 1 of 2012 in number 13 contains a new norm, namely gedrags normen and bevoegdheids normen which prohibits or limits the authority of criminal examination and prosecution of certain institutions in the enforcement of criminal law according to Article 52 KIP. The police or the prosecutor's office has the authority as if it were ordered or prohibited from examining and prosecuting criminal acts according to Article 52 of the KIP before the Information Commission issued a decision and the decision has permanent legal force. Such norms contradict the nature of a circular that only has the status of quasi statutory regulations or policies.

Thus, in the context of the Information Commission Circular Letter No. 1 of 2012 concerning Handling of Criminal Acts in the KIP Law which basically states that criminal charges in Article 52 of the KIP Law can be made when the Information Commission's decision is legally enforceable so that the criminal process without a decision on public information dispute resolution by the Information Commission is not it can be continued that in fact, the legal product is only a circular letter, so it can be understood that its validity is only for KIP itself. This means that there is no obligation for other parties to comply with the circular letter. For example, the police will examine a Public Agency that is suspected of having violated Article 52 of the KIP Law, then the Public Agency cannot immediately take shelter behind the Information Commission Circular Letter No. 1 of 2012 On the Handling of the Criminal Complaint.

The placement of criminal law enforcement as a final resort is a logical thing because philosophically, criminal law is indeed an ultimum remedium. ${ }^{37}$ Ultimum remedium is one of the principles in criminal law where criminal law should be used as a last resort in law enforcement. ${ }^{38}$ Remmelink stated that because the sanctions were in the form of threats and suffering, the application of criminal law was limited as much as possible or its use was made if other legal

${ }^{35}$ Nugraha, X., Felany, P. I., \& Rosyadi, M. I. (2015). Analisis Upaya Pemerintah Meminimalisir Risiko Gagal Bayar Dalam Pemberian Pinjaman Kepada BUMN. Majalah Hukum Nasional, 50(1), pp. 61-81. https://doi.org/10.33331/mhn.v50i1.52

${ }^{36}$ Decision of the Constitutional Court of the Republic of Indonesia Number 16/PUU-XVII/2019, p. 38-39.

${ }^{37}$ Riyanto, Agus. (2015). Eksistensi dan Kedudukan Hukum Surat Edaran Kapolri tentang Penanganan Ujaran Kebencian (Hate Speech). Jurnal Cahaya Keadilan, 3(2), pp. 1 - 13.

38 Subyakto, K. (2015). Asas Ultimum Remedium ataukah Asas Primum Remedium yang Dianut dalam Penegakan Hukum Pidana pada Tindak Pidana Lingkungan Hidup Pada UU No. 32 Tahun 2009 tentang Perlindungan dan Pengelolaan Lingkungan Hdup. Jurnal Pembaharuan Hukum, 2(2), pp. $209 \quad-\quad 213$. http://dx.doi.org/10.26532/iph.v2i2.1431 
sanctions were no longer adequate. ${ }^{39}$ In addition, it needs to be understood that the imposition of criminal sanctions should be carried out in a measured and careful manner because it is related to the policy of the elimination of freedom from human rights which is legalized by law. 40

In enforcing the law on public information disputes, other mechanisms are available that can be taken in advance, namely objection, adjudication, lawsuit and cassation. The application of the criminal mechanism as primum remedium in the context of information disclosure does not necessarily provide benefits, because it is not in line with the original goal, i.e to obtain public information, but instead turns into criminalizing the public agency or public official concerned. Today's criminal law also recognizes the concept of restorative justice which focuses on the participation of interested parties to jointly identify the losses suffered and the fulfillment of the rights that must be received. ${ }^{41}$ The mechanisms and procedures for criminal justice which initially focused on punishing the perpetrator turned into a mediation process or dialogue to reach an agreement regarding the settlement of cases that were fair and balanced for the parties. ${ }^{42}$ Thus, conflict resolution does not emphasize the wrongdoing of the perpetrator to be subject to criminal sanctions, but rather emphasizes returning to its original state. ${ }^{43}$ This concept has been manifested in a series of existing processes so that criminal law enforcement should be put in place as a last resort if the public agency does not carry out the Information Commission's decision which has permanent legal force. In addition, by enforcing criminal law as an ultimum remedium, the procedure becomes clearer and there is no possibility of conflicting decisions. This is because if a sentence is placed as a primum remedium it will cause problems when civil / state administration and criminal procedures are carried out simultaneously, i.e, there is the possibility of conflicting decisions, resulting in legal uncertainty as to which decision should be used.

In the context of placing criminal law enforcement as an ultimum remedium, which incidentally is obligatory to use other legal remedies first to create constructive law enforcement, it is necessary to have legal rules governing this matter. The ideal legal product is of course a law, but considering that the period of forming a law is not short, in the near future a concrete legal product that can be formed is an Memorandum of Understanding between the Information Commission and the National Police to synergize the two institutions in handling criminal acts of misuse of public information.

${ }^{39}$ Anindyajati, T., Rachman, I. N., \& Onita, A. A. D. (2016). Konstitusionalitas Norma Sanksi Pidana sebagai Ultimum Remedium dalam Pembentukan Perundang-undangan. Jurnal Konstitusi, 12(4), pp. 872 - 892. https://doi.org/10.31078/ik12410

40 lbid.

${ }^{41}$ Chandra, S. (2013). Restorative Justice: Suatu Tinjauan terhadap Pembaharuan Hukum Pidana di Indonesia. Jurnal Rechtsvinding, 2(2), pp. 263 - 277. http://dx.doi.ora/10.33331/rechtsvinding.v2i2.76

${ }^{42}$ Kristian, K \& Tanuwijaya, C. (2015). Penyelesaian Perkara Pidana dengan Konsep Keadilan Restoratif (Restorative Justice) dalam Sistem Pidana Terpadi di Indonesia. Jurnal Mimbar Justitia, 1(2), pp. 592 - 607. https://doi.org/10.35194/ihmi.v1i2.42

${ }^{43}$ Mareta, J. (2019). Penerapan Restorative Justice Melalui Pemenuhan Restitusi pada Korban Tindak Pidana Anak. Jurnal Legislasi Indonesia, 15(4), pp. 309 - 319. 
In short, memorandum of understanding is an agreement made between one legal subject and another ${ }^{44}$, both within a state and between states to cooperate in various aspects of life for a certain period of time. ${ }^{45}$ According to Munir Fuady, the Memorandum of Understanding is a preliminary agreement that regulates only basic matters. This means that the Memorandum of Understanding will be followed and explained in a more complete and detailed manner by the parties in the other agreement. ${ }^{46}$ For example, matters relating to technical implementation can be further regulated in technical instructions such as work guidelines, implementation guidelines, Standard Operating Procedures (SOP) or other forms agreed by the parties.

An example of a Memorandum of Understanding is the Memorandum of Understanding established by the Corruption Eradication Commission (KPK), Police, and the Attorney General's Office on Cooperation in the Eradication of Corruption, which aims to optimize the eradication of corruption in Indonesia by synergizing three institutions that legally have the authority to handle corruption cases. Another example is the Memorandum of Understanding between the General Election Commission and the National Police on Safeguarding the Implementation of the Election for the Governor and Deputy Governor, the Regent and Deputy Regent, and/or the Mayor and Deputy Mayor. This shows that the Memorandum of Understanding is commonly used as an instrument of cooperation to optimize the implementation of the duties, functions, and powers of the parties involved in it.

Article 12 Information Commission Decree No. 03/KEP/KIP/IV/2010 On The Guidelines for the Institutional Cooperation of the Information Commission stated that the Information Commission could hold a Memorandum of Understanding as an instrument of institutional cooperation for the Information Commission. Collaboration can be carried out within the scope of socialization, education, advocacy, technical assistance, consultative, study, and/or publication activities in the form of financial assistance, management, human resources, infrastructure, promotion/publication, and/or certain programs. Apart from that in Article 8 of the Regulation of the Head of the Indonesian Police No. 12/2014 on The Guidelines for the Compilation of National Police Cooperation in the Republic of Indonesia also states that the National Police may cooperate in the form of a Memorandum of Understanding or other forms following statutory regulations. Thus, this Memorandum of Understanding already has a juridical basis for implementation by both the Information Commission and the National Police.

In the case of law enforcement of public information disputes, this Memorandum of Understanding aims to synergize the Information Commission and the National Police so that a clear mechanism is created in case the Information Commission's decision is legally enforceable

${ }^{44}$ The legal subjects in the Memorandum of Understanding include public legal entities (eg State, state institutions, Provincial Governments, District /City Governments, government/non-government agencies) as well as private legal entities (for example Limited Liability Companies, Cooperatives, Foundations).

${ }^{45}$ Salim, H. S., et.al. (2011). Perancangan Kontrak \& Memorandum of Understanding. Cet. ke-5. Jakarta: Sinar Grafika, p. 47.

${ }_{46}$ Ibid, p. 46 
and confirms the position of each party in the law enforcement process. The existence of a Memorandum of Understanding between the Information Commission and the National Police is arguably better than a legal product with a status a quo in the form of Information Commission Circular Letter No. 1 of 2012 which incidentally is only binding for the information commission. With this Memorandum of Understanding, not only the information commission, but the police will also comply with the provisions that place criminal law enforcement in Article 52 of the KIP Law as ultimum remedium. In addition, the Memorandum of Understanding is expected to form and strengthen institutional networks to streamline the implementation of KIP Law and all its implementing regulations.

Broadly speaking, the Memorandum of Understanding process consists of the initiation stage, the discussion stage (both internally and with the parties that will cooperate), signing, implementing as well as monitoring and evaluation. The Memorandum of Understanding becomes effective and binding after being agreed and signed by the parties in a predetermined period of time. Meanwhile, regards to Article 28 of the Regulation of the Head of the Indonesian Police No. 12 of 2014, cooperation ends if agreed by the parties through the procedures set out in the Memorandum of Understanding, the objectives of the cooperation have been achieved, there are fundamental changes that affect the implementation of cooperation, one party does not implement and/or violates the provisions of the Memorandum of Understanding, New cooperation that replaces old cooperation, new norms appear in applicable law, objects of cooperation are lost or there are things that are detrimental to the national interest.

The Memorandum of Understanding between the Information Commission and the National Police contains at least:

a. Title. For example, the Memorandum of Understanding between the Central Information Commission and the National Police of the Republic of Indonesia regarding Cooperation in the Handling of Crimes in Public Information Disputes.

b. Identity of the Parties. Mention the leadership (chairman/head) of the Central Information Commission and the Indonesian National Police, who in this case act for and on behalf of each institution.

c. Background. Explain the institution and the reasons for the need for a Memorandum of Understanding between the Information Commission and the National Police, namely creating a clear mechanism for handling criminal acts of public information disputes. Apart from that, it also mentions related laws and regulations.

d. Purpose and objectives. Explain that the Memorandum of Understanding was made to serve as a guideline for parties in handling criminal acts in public information disputes. Meanwhile, the purpose of the Memorandum of Understanding is to increase synergy and coordination between the parties in handling criminal acts in public information disputes. 
e. Scope. Describe the contents of the cooperation including the mechanism for enforcing public information disputes.

f. Monitoring and Evaluation. To determine the implementation of monitoring and evaluation of the implementation of the Memorandum of Understanding, for example, it will be carried out periodically at least 2 (two) times a year.

g. Liaison Officer. State the liaison officer/person in charge for the implementation of the Memorandum of Understanding.

h. Change (Amendment). Regulate if the parties wish to make changes to the substance of the cooperation or there are other things deemed necessary and have not been regulated in the Memorandum of Understanding.

i. Period. Regulate when the cooperation takes effect, the length of time the cooperation is carried out, the extension of cooperation, and if one of the parties wishes to terminate the Memorandum of Understanding before the end of the period.

j. Differences in Interpretation. Arranging a settlement in the event of a difference in the interpretation and/or implementation of the Memorandum of Understanding, which will be resolved by deliberation to reach a consensus by the parties

k. Closing and Signatures of the Parties

As for the substance of this Memorandum of Understanding, at least it must contain 3 (three) main points, i.e in terms of 1) Law Enforcement, 2) Assistance to Resource Persons/Experts/Witnesses, and 3) Exchange of Data and/or Information. The first is from the aspect of law enforcement. In this aspect, what is regulated in essence are:

1. Law enforcement carried out by the Police in this Memorandum of Understanding includes criminal acts as stipulated in Article 52 of the KIP Law.

2. Criminal charges in criminal acts as referred to in Article 52 of the KIP Law can only be carried out when the verdict with legal force remains not implemented by the public agency concerned. Decisions with legal force are still decisions obtained through law enforcement mechanisms as stipulated in the UU KIP in addition to being a criminal.

3. The police cannot accept or process a criminal complaint as referred to in Article 52 of the KIP Law without a final legally binding decision.

4. In such a case, the Police directs the complaining party to first proceed with an objection, non-litigation adjudication, lawsuit, and cassation.

Through an arrangement like this, it will be clear who is authorized and when the police have the authority to handle criminal acts of public information disputes. The existence of a constructive regulation of this aspect of law enforcement, will create law enforcement related to requests for constructive public information and reflect the principle of legal certainty.

The second is the arrangement of the aspect of resource/expert/witness assistance. In this aspect, it is principally regulated, that the parties can assist each other as 
sources/experts/witnesses in carrying out their duties and authorities. This is intended, when police investigators need an Information Commission as a resource/expert/witness in carrying out their duties and authorities, it can be carried out well. For example, in the case of law enforcement training related to requests for information commissions, it is possible to request assistance from the Information Commission as a resource. The existence of regulations in this aspect aims to ensure that law enforcement related to requests for public information can be integrated (integrated) and constructive so that views on cases related to requests for information do not conflict with one another.

The third is the arrangement of the Data and/or Information Exchange aspect. In this aspect it is principally regulated, that:

1. The parties can request and/or provide data and/or information related to the implementation of their respective duties and authorities following the laws and regulations.

2. Requests for and/or data and/or information shall be submitted in writing and signed by the authorized official, accompanied by an explanation of the purposes and purposes for using the data and/or information.

3. Requests for and/or provision of data and/or information can be submitted electronically or non-electronically and coordinated through the respective liaison/person in charge based on the provisions of laws and regulations.

The existence of regulations in this aspect aims to create law enforcement related to integrated requests for information between the National Police and the Information Commission so that law enforcement is constructive and reflects the principle of legal certainty.

\section{CONCLUSION}

Law enforcement in the settlement of public information disputes consists of law enforcement through objection, non-litigation adjudication, and civil litigation, state administration, and criminal litigation. The formulation of a mechanism to create constructive law enforcement in the settlement of public information disputes is to place criminal law enforcement as the final step in the dispute resolution process (ultimum remedium). The applicant for information cannot criminally report the public agency involved if he has not gone through the process of the complaint, non-litigation adjudication, lawsuit, or cassation. Criminal law enforcement is only carried out if the relevant public body does not carry out a decision that has permanent legal force (inkracht van gewijsde). In addition, cooperation and coordination between the Information Commission and the National Police through a Memorandum of Understanding is needed to streamline the handling of criminal acts of public information disputes. The formulation of the Memorandum of Understanding will at least regulate 3 main things, namely law enforcement, namely who is authorized and when the police have the authority to handle criminal acts of public 
information disputes, the assistance of sources/experts/witnesses, and exchange of data and/or information between the Information Commission and the Police.

\section{REFERENCE}

Anindyajati, T., Rachman, I. N., \& Onita, A. A. D. (2016). Konstitusionalitas Norma Sanksi Pidana sebagai Ultimum Remedium dalam Pembentukan Perundang-undangan. Jurnal Konstitusi, 12(4), pp. 872 - 892. https://doi.org/10.31078/ik12410

Aryani P., Dyah, et.al. (2015). Putusan Komisi Informasi dalam Bingkai Hukum Progresif. Jakarta: Komisi Informasi Pusat Republik Indonesia.

Asshidiqie, J. (2006). Hukum Tata Negara dan Pilar-Pilar Demokrasi, Serpihan Pemikiran Hukum, Media dan HAM. Jakarta: Syaamil Cipta Media.

Barus, Z. (2013). Analisis Filosofis tentang Peta Konseptuan Penelitian Hukum Normatif dan Penelitian Hukum Sosiologis. Jurnal Dinamika Hukum, 13(2), pp. 307 - 318. http://dx.doi.org/10.20884/1.jdh.2013.13.2.212

Belinfante A. D. (1983). Pokok-Pokok Hukum Tata Usaha Negara. Jakarta: Bina Cipta

Cahyo, A. N. (2013). Panduan Aplikasi Teori-Teori Belajar Mengajar Teraktual dan Terpopuler. Jogjakarta: Diva Pers.

Chandra, S. (2013). Restorative Justice: Suatu Tinjauan terhadap Pembaharuan Hukum Pidana di Indonesia. Jurnal Rechtsvinding, 2(2), pp. 263 - 277. http://dx.doi.org/10.33331/rechtsvindinq.v2i2.76

Decision of the Constitutional Court of the Republic of Indonesia Number 16/PUU-XVII/2019

Erwin, M. (2012). Filsafat Hukum. Jakarta: Raja Grafindo.

Febrianingsih, N. (2012). Keterbukaan Informasi Publik dalam Pemerintahan Terbuka Menuju Tata Pemerintahan yang Baik. Jurnal Rechtsvinding, 1(1), pp. 135 - 156. http://dx.doi.org/10.33331/rechtsvinding.v1i1.110

Furqon, E. (2020). Kedudukan Lembaga Negara Independen Berfungsi Quasi Peradilan dalam Sistem Ketatanegaraan Indonesia. Jurnal Nurani Hukum, 3(1), pp. 77 - 85. http://dx.doi.org/10.51825/nhk.v3i1.8523

Haugen, T., \& Singh, A. (2015). Dispute Resolution Strategy Selection. Journal of Legal Affairs and Dispute Resolution in Engineering and Construction Vol, 7(3). https://doi.org/10.1061/(ASCE)LA.1943-4170.0000160

Indratanto, S. P., Nurainun, N., \& Kleden, K. L. (2020). Asas Kepastian Hukum Dalam Implementasi Putusan Mahkamah Konstitusi Berbentuk Peraturan Lembaga Negara Dan Peraturan Pemerintah Pengganti Undang-Undang. DIH: Jurnal IImu Hukum, 16(1), pp. 88 - 100. https://doi.org/10.30996/dih.v16i1.2729

KIP Law and Information Commissions Regulation No. 1 of 2010 On The Public Information Service Standards. 
Kordela, M. (2008). The Principle of Legal Certainty as a Fundamental Element of the Formal Concept of the Rule of Law. Revue Du Notariat, 2(1), pp. 590 - 598. https://doi.org/10.7202/1045553ar

Korua, R. V. (2020). Kajian Hukum Putusan Bebas (Vrijspraak) dalam Perkara Pidana. Lex Crimen, 9(4), pp. $234-243$.

Kristian, K \& Tanuwijaya, C. (2015). Penyelesaian Perkara Pidana dengan Konsep Keadilan Restoratif (Restorative Justice) dalam Sistem Pidana Terpadi di Indonesia. Jurnal Mimbar Justitia, 1(2), pp. 592 - 607. https://doi.org/10.35194/ihmi.v1i2.42

Kristiyanto, E. N. (2016). Urgensi Keterbukaan Informasi dalam Penyelenggaraan Pelayanan Publik (Urgency of Disclosure of Informationin the Implementation of Public Service). Jurnal Penelitian Hukum De Jure, 16(2), pp. 231 - 244. http://dx.doi.org/10.30641/dejure.2016.V16.231-244

Lamintang, P.A.F. (1997). Dasar-Dasar Hukum Pidana Indonesia. Bandung: Citra Aditya Bakti.

Lolita, A \& Abudan, M. (2018). Kewenangan Komisi Informasi dalam Mengadili Sengketa Informasi Publik (Studi Kasus: Forum Diskusi Suporter Indonesia Melawan Persatuan Sepak Bola Seluruh Indonesia, Jurnal Hukum Adigama, 1(1), pp. 1 - 25. http://dx.doi.org/10.24912/adigama.v1i1.2134

Mareta, J. (2019). Penerapan Restorative Justice Melalui Pemenuhan Restitusi pada Korban Tindak Pidana Anak. Jurnal Legislasi Indonesia, 15(4), pp. 309 - 319.

Marzuki, M. (2017). Penelitian Hukum (Edisi Revisi). Jakarta: Kencana Prenadamedia Group.

Mushi, A. (2018). Pemenuhan Hak atas Informasi Publik sebagai Tanggung Jawab Negara dalam Mewujudkan Good Governance. Lentera Hukum, 5(1), pp. 63 - 76. https://doi.org/10.19184/ejlh.v5i1.7284

Naelufar, R. (2013). Perluasan Kompetensi PTUN dalam Mengadili Sengketa Informasi Publik. UNNES Law Journal, 2(1), pp. 64 - 72. https://doi.org/10.15294/uli.v2i1.2905

Nugraha, X., Felany, P. I., \& Rosyadi, M. I. (2015). Analisis Upaya Pemerintah Meminimalisir Risiko Gagal Bayar Dalam Pemberian Pinjaman Kepada BUMN. Majalah Hukum Nasional, 50(1), pp. 61-81. https://doi.org/10.33331/mhn.v50i1.52

Nugraha, X., \& Katherina, A. M. F. (2019). Tanggungjawab Promotor Perseroan Terbatas Terhadap Kontrak Prainkorporasi Di Indonesia. Media luris, 2(1), pp. 99 - 128.

Prasetyo, T. (2016). Penyelesaian Sengketa Keterbukaan Informasi Publik di Pengadilan Tata Usaha Negara Semarang. Jurnal Spektrum Hukum, 13(2), p. 238 - 261. http://dx.doi.org/10.35973/sh.v13i2.1091

Riyanto, Agus. (2015). Eksistensi dan Kedudukan Hukum Surat Edaran Kapolri tentang Penanganan Ujaran Kebencian (Hate Speech). Jurnal Cahaya Keadilan, 3(2), pp. 1 - 13. 
Risnan, M. (2014). Eksistensi Lembaga Quasi Judicial dalam Sistem Kekuasaan Kehakiman: Kajian Terhadap Komisi Persaingan Usaha', Jurnal Hukum dan Peradilan, 3(1), pp. 49 58.

Retnowati, E. (2012). Keterbukaan Informasi Publik dan Good Governance (Antara Das Sein dan Das Sollen). Perspektif, 17(1), pp. 54 - 61. http://dx.doi.org/10.30742/perspektif.v17i1.94

Salim, H. S., et.al. (2011). Perancangan Kontrak \& Memorandum of Understanding. Cet. ke-5. Jakarta: Sinar Grafika.

Saraya, Sitta. (2019). Tindak Pidana Keterbukaan Informasi Publik di Indonesia Sebuah Kajian Perbandingan Sistem Pemidanaan di Negara Asing Thailand dan Jepang. Jurnal lus Constituendum, 4(2), pp. 128 - 146. http://dx.doi.org/10.26623/iic.v4i2.1653

Simamora, J. (2014). Kepastian Hukum Pengajuan Kasasi oleh Jaksa Penuntut Umum terhadap Vonis Bebas: Kajian Putusan Mahkamah Konstitusi Nomor 114/PUU-X/2012. Jurnal Yudisial, 7(1), pp. 1 - 17. http://dx.doi.org/10.29123/iy.v7i1.90

Simanjutak, E. (2019). Peran Yurispridensi dalam Sistem Hukum Indonesia. Jurnal Konstitusi, 16(1), pp. 83 - 104. https://doi.org/10.31078/ik1615

Sonata, D. L. (2014) Metode Penelitian Hukum Normatif dan Empiris: Karakteristik Khas dari Metode Meneliti Hukum. Fiat Justitia Jurnal IImu Hukum, 8(1), pp. 15 - 35.

Sunarko, T. A., Jaya, I. N. S. P., \& Purwoto. (2012). Pertanggungjawaban Pidana Pejabat Publik terhadap Tindak Pidana Kebohongan Publik dalam Undang-Undang Nomor 14 Tahun 2008 Tentang Keterbukaan. Diponegoro Law Journal, 1(4), pp. 2 - 11.

Subyakto, K. (2015). Asas Ultimum Remedium ataukah Asas Primum Remedium yang Dianut dalam Penegakan Hukum Pidana pada Tindak Pidana Lingkungan Hidup Pada UU No. 32 Tahun 2009 tentang Perlindungan dan Pengelolaan Lingkungan Hdup. Jurnal Pembaharuan Hukum, 2(2), pp. 209 - 213. http://dx.doi.org/10.26532/jph.v2i2.1431

Yarni, M. \& Amir, L. (2014). Penguatan Tata Kelola Pemerintahan yang Baik dalam Pembentukan Peraturan Perundang-Undangan sebagai Pilar Penegakan Hak Asasi Manusia di Indonesia. Jurnal IImu Hukum Jambi, 6(1), pp. 120 - 138. 